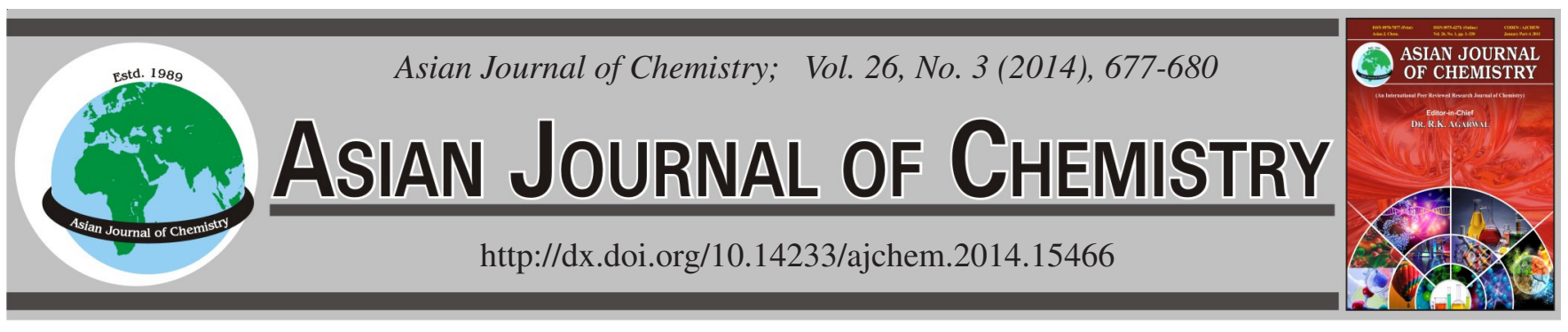

\title{
Determination of Dopamine in the Presence of Ascorbic Acid Using Silver-Diethyldithiocarbamate Modified Electrode
}

\author{
Yue-Ying LiU and ShI-Hao Zhao*
}

College of Biological Science and Engineering, Hebei University of Economics and Business, Shijiazhuang 050061, P.R. China

*Corresponding author: Tel: +86 311 87656833: E-mail: zhaoshihao_1@163.com

\begin{abstract}
A glassy carbon electrode (GCE) was modified with silver-diethyldithiocarbamate (DDTC Ag) modified electrode has been constructed. The DDTC Ag modified electrode showed an excellent electrocatalytical effect on the oxidation of dopamine. In the $\mathrm{pH} 2.56$ buffer solution, the oxidation peak of dopamine was linear with its concentration from $5.0 \times 10^{-7}-6.0 \times 10^{-5} \mathrm{~mol} \mathrm{~L}^{-1}$, detect limit of it reached $1.0 \times 10^{-7} \mathrm{~mol} \mathrm{~L}^{-1}$. Moreover, the interference of ascorbic acid with the determination of dopamine could be eliminated. The method could obtain better result when it applied to the determination dopamine in serum and medical samples.
\end{abstract}

Keywords: Silver-diethyldithiocarbamate, Modified electrode, Dopamine, Ascorbic acid.

\section{INTRODUCTION}

Dopamine (DA), the most significant catecholamine, belongs to the family of inhibitory neurotransmitters and plays an important role in the functioning of central nervous, renal, hormonal and cardiovascular system. Extreme abnormalities of dopamine concentration levels may lead to several diseases such as Parkinson's ${ }^{1,2}$. Therefore, dopamine has been given tremendous consideration in biomedical investigation and there is a strong need to establish sensitive, selective and reliable methods for the direct measurement of dopamine. Thus, various commonly used analytical methods for the detection of dopamine had been developed in the past, including capillary electrophoresis $(\mathrm{CE})^{3}$, high-performance liquid chromatography $(\text { HPLC })^{4,5}$, spectrofluorimetry ${ }^{6}$, chemiluminescence $(\mathrm{CL})^{7}$ and competitive enzyme-linked immunosorbent assay method ${ }^{8}$. These methods were very sensitive. However, most of these techniques required a compressing system, temperature control, separation and other spectrophotometric or electric detection system.

Being an electroactive molecule and due to its importance in the central nervous system ${ }^{9,10}$, the electrochemical detection of dopamine had received much interest. It is generally believed that direct redox reactions of dopamine at bare electrode are irreversible and therefore require high overpotentials ${ }^{11,12}$. Moreover, the direct redox reaction of dopamine at the bare electrode take place at very similar potentials with other coexist substrates and often suffer from a pronounced fouling effect, which results in rather poor selectivity and reproducibility. A promising approach to overcome difficulties arising from overpotential problems and fouling properties of the biological substrate is the use of chemically modified electrodes (CMEs), such as a poly (isonicotinic acid $)^{13}, \operatorname{poly}(p \text {-nitrobenzenazo resorcinol })^{11}$, nanocluster overoxidized-polypyrrole composite ${ }^{14}$ and nickel hexacyanoferrate and poly(1-naphthol) hybrid film ${ }^{15}$ were used to modify the different electrode for the detection of determine dopamine, however, there had no report about silver-diethyldithiocarbamate (DDTC Ag) modified electrode as applied to the determination of dopamine.

We describe herein a simple and rapid method to prepare the DDTC Ag modified electrode and a new method for the determination of dopamine has been established at the modified electrode. The results indicated this electrode not only prepared simply but also had higher sensitivity and alternative in detecting dopamine. The proposed method has been applied to the determination of dopamine in serum and medical samples with satisfactory result.

\section{EXPERIMENTAL}

Cyclic voltammetrys measurements were carried out using a MEC-12B multi-function electrochemical analyzer (Jiangsu Jiangfen Instrument Int., China). All the cyclic voltammograms were made using a three-electrode system with a glassy carbon electrode as a working electrode, an $\mathrm{Ag} / \mathrm{AgCl}$ (saturated with $\mathrm{KCl}$ ) as a reference electrode and a platinum wire electrode as a counter electrode. The KQ218 ultrasonic instrument (Kunshan Ultrasonic Instrument Factory, China) was used. 
Dopamine (Aladdin Reagent Co., Ltd.), ascorbic acid (Shanghai No. 4 Reagent \& H.V. Chemical Co., Ltd.). All other chemical reagents were used without further purification. All other chemicals used in this investigation were of analytical grade. $0.05 \mathrm{~mol} \mathrm{~L}^{-1} \mathrm{H}_{3} \mathrm{PO}_{4}+0.05 \mathrm{~mol} \mathrm{~L}^{-1} \mathrm{CH}_{3} \mathrm{COOH}+0.05$ mol L ${ }^{-1} \mathrm{H}_{3} \mathrm{BO}_{3}-0.2$ mol L-1 $\mathrm{NaOH}$ buffer solutions of various pHs were prepared by mixing two stock solutions, ascorbic acid and dopamine were prepared daily. All solutions were prepared with double-distilled water.

Preparation of DDTCAg modified electrode: Glass carbon electrodes were polished first with emery paper, alumina $(0.1$ $\mathrm{mm})$ and then cleaned in an ultrasonic bath in $(1: 1) \mathrm{HNO}_{3}$, (1:1) $\mathrm{CH}_{3} \mathrm{CH}_{2} \mathrm{OH}$ and water in turn. After rinsing with water, the electrodes were cyclically scanned in $0.5 \mathrm{~mol} \mathrm{~L}^{-1} \mathrm{H}_{2} \mathrm{SO}_{4}$ (from -0.8 to $1.2 \mathrm{~V}$ ) until a reproducible voltammogram was obtained. The GCE was coated by casting $10 \mu \mathrm{L}$ dispersion of DDTC Ag (0.1 g DDTC Ag dissolved in $2 \mathrm{~mL} \mathrm{CCl}_{4}$ at a brown volume) and dried at room temperature. The freshly prepared DDTC Ag modified electrode was activated in $\mathrm{pH} 2.56(0.05$ $\mathrm{mol} \mathrm{L}{ }^{-1} \mathrm{H}_{3} \mathrm{PO}_{4}+0.05 \mathrm{~mol} \mathrm{~L}^{-1} \mathrm{CH}_{3} \mathrm{COOH}+0.05 \mathrm{~mol} \mathrm{~L}^{-1} \mathrm{H}_{3} \mathrm{BO}_{3}^{-}$ $0.2 \mathrm{~mol} \mathrm{~L}^{-1} \mathrm{NaOH}$ ) buffer solution. By using successive cyclic scans from $-0.8 \mathrm{~V}$ to $1.0 \mathrm{~V}$. The electrode was thoroughly washed with doubly distilled water before use.

Method: The cyclic voltammetry was used in the determination of dopamine. Potential scanning was performed in the range of -0.3 to $0.7 \mathrm{~V}$, the accumulation potential was $-0.3 \mathrm{~V}$, the accumulation time was $0.5 \mathrm{~min}$ and the scan rate was 100 $\mathrm{mV} \mathrm{s}^{-1}$. At the same time wrote down cyclic voltammograms for investigating the cyclic voltammetric behaviours of dopamine on DDTC Ag modified electrode.

\section{RESULTS AND DISCUSSION}

Electrochemical behaviour of dopamine at the DDTC Ag modified electrode: Fig. 1a,c showed the cyclic voltammograms (CVs) of the flat glassy carbon electrode in the blank solution ( $\mathrm{pH} 2.56$ ). Upon the addition of $2.0 \times 10^{-5} \mathrm{~mol} \mathrm{~L}^{-1}$ dopamine, which exhibited poor electrochemical response at the bare GCE Fig. $1 \mathrm{~b}$. The peak potential separate value $\left(\Delta \mathrm{E}_{\mathrm{p}}\right)$ between the oxidation peak potential $\left(\mathrm{E}_{\mathrm{pa}}=0.25 \mathrm{~V}\right)$ and the reduction potential $\left(\mathrm{E}_{\mathrm{pc}}=0.15 \mathrm{~V}\right)$ was $100 \mathrm{mV}$. But at the DDTC Ag modified electrode Fig. 1d, dopamine exhibited good electrochemical response and the voltammograms showed a pair of obvious redox peaks with the potential value of the oxidation and the reduction peak being 0.26 and $0.22 \mathrm{~V}$, respectively. So the peak potential separate value $\left(\Delta \mathrm{E}_{\mathrm{p}}\right)$ was $40 \mathrm{mV}$. Compared with that at flat electrode, the peak potential separate value $\left(\Delta \mathrm{E}_{\mathrm{p}}\right)$ decreased and the redox peaks current increased obviously. These results indicate the strong electrocatalytic activity of the DDTC Ag modified electrode to dopamine.

Furthermore, the effect of the scan rate on the oxidation peak of dopamine was investigated. The oxidation peak potential positive shifted slightly and the reduction peak potential negative shifted slightly with increasing scan rate, it indicated the electrode reaction was quasi-reversible. And the oxidation peak current $\mathrm{i}_{\mathrm{Pa}}$ was proportional to the scan rate at lower scan rate $25-250 \mathrm{mV} \mathrm{s}^{-1}$. The linear regression equation was $\mathrm{i}_{\mathrm{Pa}}(\mu \mathrm{A})=0.5706+0.6326 \nu\left(\mathrm{mV} \mathrm{s}^{-1}\right.$ with a correlation coefficient of $\mathrm{R}=0.9995$. It followed Langmuir adsorption isotherm:

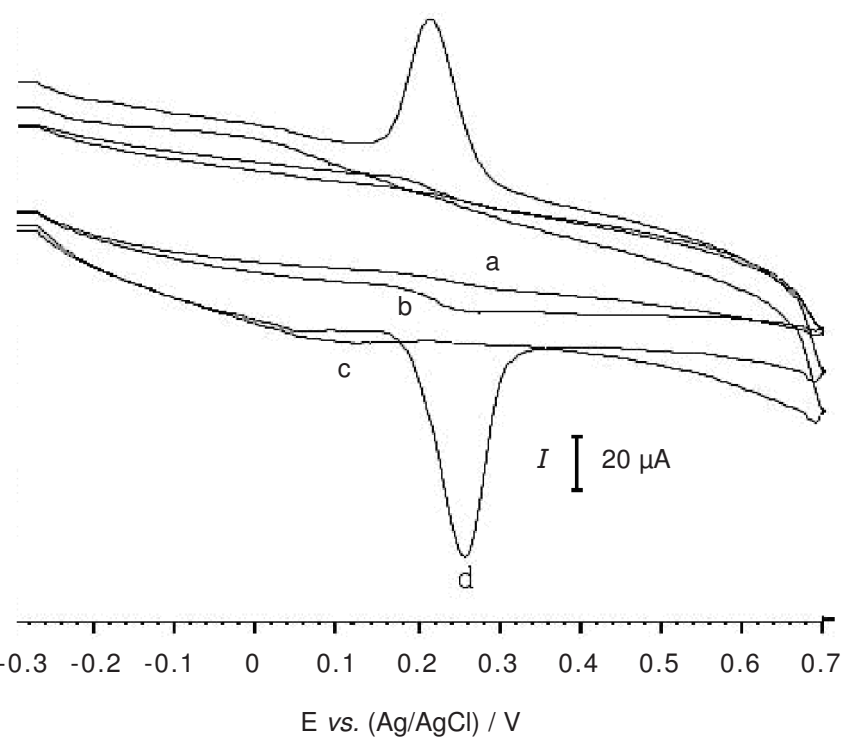

Fig. 1. CVs of dopamine at the DDTC Ag modified electrode and flat in electrode $\mathrm{pH} 2.56$ buffer solution. a, c: in the blank solution; b, d: $1.0 \times 10^{-5} \mathrm{~mol} \mathrm{~L}^{-1}$ dopamine solution

$$
\mathrm{i}_{\mathrm{P}}=\frac{\mathrm{n}^{2} \mathrm{~F}^{2} \mathrm{~A} \Gamma_{\mathrm{T}} \mathrm{V}}{4 \mathrm{RT}}
$$

It indicated that electrode process was controlled by adsorption. But the relationship between the oxidation peak current and the scan rate was not linear at higher scan rate (> $250 \mathrm{mV} \mathrm{s}^{-1}$ ), the curve bended down to another line region, the exponential relation between $i_{\mathrm{P}}$ and scan rate translated from 1-1/2. The reason maybe that the reaction accelerated the depletion of $\mathrm{H}^{+}$which on the surface of electrode in the solution, as a result, the diffusion layer was formed. So electrode process was controlled by surface adsorption at the lower scan rate, while reaction rate and surface diffusion were dominant at the higher scan rate.

In addition, the effects of the background solution and the $\mathrm{pH}$ value on the response of dopamine were studied in $\mathrm{KH}_{2} \mathrm{PO}_{4}-\mathrm{NaOH}, \mathrm{CH}_{3} \mathrm{COOH}-\mathrm{CH}_{3} \mathrm{COONa}, \mathrm{HCl}, \mathrm{KCl}$ and $\mathrm{H}_{3} \mathrm{PO}_{4}$ $\left.+\mathrm{CH}_{3} \mathrm{COOH}+\mathrm{H}_{3} \mathrm{BO}_{3}-\mathrm{NaOH}\right)$ buffer solutions. The experiment indicated that the oxidation peak was the most sensitive in $\mathrm{pH}$ $2.560 .05 \mathrm{~mol} \mathrm{~L}^{-1} \mathrm{H}_{3} \mathrm{PO}_{4}+0.05 \mathrm{~mol} \mathrm{~L}^{-1} \mathrm{CH}_{3} \mathrm{COOH}+0.05 \mathrm{~mol}$ $\mathrm{L}^{-1} \mathrm{H}_{3} \mathrm{BO}_{3}-0.2 \mathrm{~mol} \mathrm{~L} \mathrm{~L}^{-1} \mathrm{NaOH}$ buffer solution. Fig. 2 showed that the oxidation peak current increased with increasing solution $\mathrm{pH}$ until it reached 2.56. When the $\mathrm{pH}>2.56$, the oxidation peak current decreased. Since $\mathrm{pH} 2.56\left(.05 \mathrm{~mol} \mathrm{~L}^{-1}\right.$ $\mathrm{H}_{3} \mathrm{PO}_{4}+0.05 \mathrm{~mol} \mathrm{~L}^{-1} \mathrm{CH}_{3} \mathrm{COOH}+0.05 \mathrm{~mol} \mathrm{~L}^{-1} \mathrm{H}_{3} \mathrm{BO}_{3}-0.2$ mol L-1 $\mathrm{NaOH}$ ) was chosen for the support electrolyte in the electrochemical detection of dopamine.

At proposed condition, The oxidation peak current of dopamine was linear with its concentration from $5.0 \times 10^{-7}$ $6.0 \times 10^{-5} \mathrm{~mol} \mathrm{~L}^{-1}$ with the linear regression equation was $\mathrm{I}_{\mathrm{Pc}}$ $(\mu \mathrm{A})=2.562+63.983 \mathrm{c}\left(\mathrm{c}: 10^{-5} \mathrm{~mol} \mathrm{~L}^{-1}, \mathrm{R}=0.9992\right)$. Detect limit of it reached $1.0 \times 10^{-7} \mathrm{~mol} \mathrm{~L}^{-1}$.

Separation of ascorbic acid and dopamine oxidation peaks at DDTC Ag modified electrode: Ascorbic acid coexists with dopamine in the extracellular fluid of the central nervous system and its concentration is much higher than that of dopamine. It can be oxidized at a potential near to that of dopamine at 


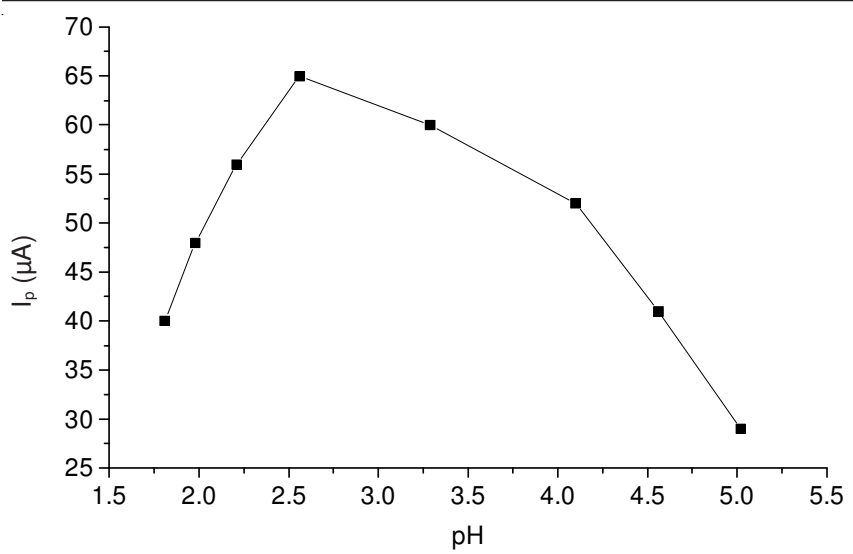

Fig. 2. Relationship between $\mathrm{pH}$ and the peak current of dopamine

most solid electrodes, separate determination of these species is a great problem due to overlapped signal. To evaluate the sensitivity and selectivity of the present system for the quantification of dopamine, the separation of ascorbic acid and dopamine oxidation peaks at the DDTC Ag modified electrode was studied. Fig. 3 showed the CVs of a mixture of ascorbic acid and dopamine at flat glassy carbon electrode and at DDTC Ag modified electrode in $\mathrm{pH} 2.56$ buffer solution. In the Fig. 3, the curves (a) and (b) correspond to the oxidation of a mixture of $2.0 \times 10^{-4} \mathrm{~mol} \mathrm{~L}^{-1}$ ascorbic acid and $1.0 \times 10^{-5} \mathrm{~mol} \mathrm{~L}^{-1}$ dopamine at flat electrode and DDTC Ag modified electrode, respectively. As expected, the bare electrode could not separate the responses of dopamine and ascorbic acid and a poor current response was observed. In contrast, two well-defined oxidation peaks at the potential of +0.06 and $+0.26 \mathrm{~V}$ were observed at the DDTC Ag modified electrode, respectively. The difference between the two peak potentials is about $200 \mathrm{mV}$. Compared with the oxidation peak of dopamine alone, it moved downwards bodily when large amount of ascorbic acid coexisted, but the oxidation peak current value was almost unchanged (Fig. 4),

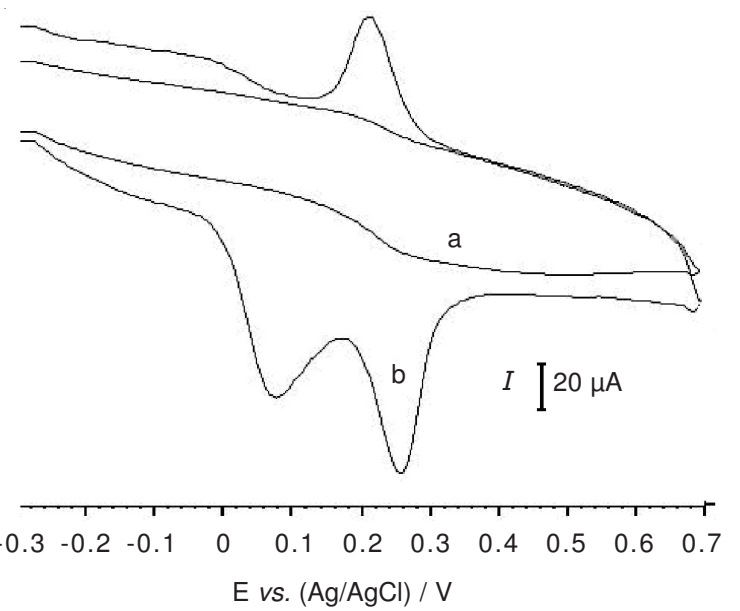

Fig. 3. CVs of $1.0 \times 10^{-5} \mathrm{~mol} \mathrm{~L}^{-1}$ dopamine and $2.0 \times 10^{-4} \mathrm{~mol} \mathrm{~L}^{-1}$ ascorbic acid at the DDTC Ag modified electrode (a) and the flat electrode (b)

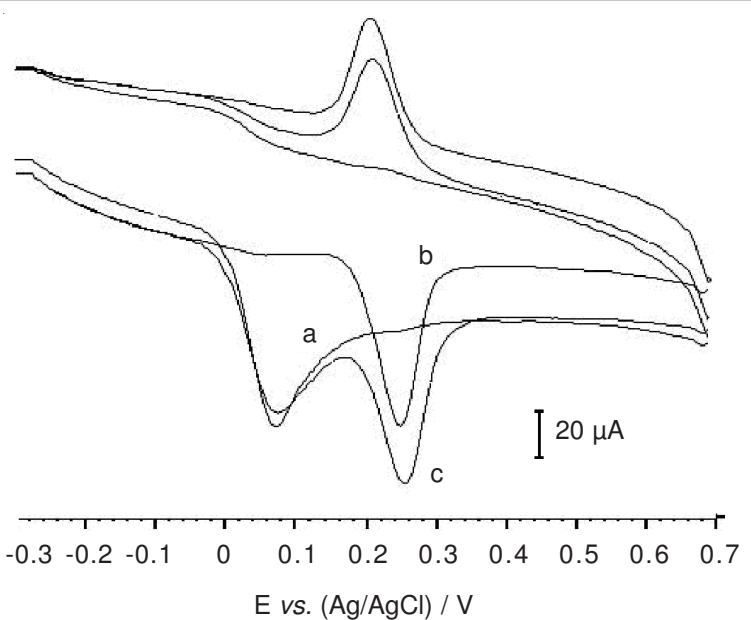

Fig. 4. CVs of dopamine and ascorbic acid at the DDTC Ag modified electrode a, $2.0 \times 10^{-4} \mathrm{~mol} \mathrm{~L}^{-1}$ ascorbic acid; b, $1.0 \times 10^{-5} \mathrm{~mol} \mathrm{~L}^{-1}$ dopamine; c, $1.0 \times 10^{-5} \mathrm{~mol} \mathrm{~L}^{-1}$ dopamine $+2.0 \times 10^{-4} \mathrm{~mol} \mathrm{~L}^{-1}$ ascorbic acid

which is sufficient enough for the quantification of dopamine in a mixture.

Effect of interferences: The influences of some common inorganic ions and a couple of relevant organic compounds on CL intensities were investigated also for measuring $1.0 \times$ $10^{-5} \mathrm{~mol} \mathrm{~L}^{-1}$ dopamine. The tolerable concentration ratios with respect to $1.0 \times 10^{-5} \mathrm{~mol} \mathrm{~L}^{-1}$ dopamine standard solution for interference at less than $5 \%$ level were over: 1000 for $\mathrm{K}^{+}$, $\mathrm{Na}^{+}, \mathrm{Ca}^{2+}, \mathrm{Cl}^{-}, \mathrm{Mg}^{2+}, 500$ for glucose, lactic acid; 50 for $\mathrm{Fe}^{3+}$, $\mathrm{Zn}^{2+}$, L-glutamic acid, glycine, uric acid, citric acid, respectively. Thus, the results demonstrated the good selectivity of this method for CVs of dopamine.

Real sample analysis: The investigated method was validated for the determination of dopamine in human serum samples.

For the medical samples, a $0.5 \mathrm{~mL}$ sample from dopamine hydrochloride injection (Shanghai Hefeng Chemicals, China) was taken to measure accuracy. The values of experimentally determined dopamine were compared to the labeled dopamine amounts in injections. The medical samples determined for 7 times by the CVs and the amount of dopamine was determined using $\mathrm{I}_{\mathrm{Pc}}$. The results are summarized in Table-1.

For the human serum samples, Drug-free human blood, obtained from healthy volunteers, was centrifuged at $3000 \mathrm{rpm}$ for $0.5 \mathrm{~h}$ at room temperature. A $1.5 \mathrm{~mL}$ of acetonitrile was added to a $2 \mathrm{~mL}$ serum sample to remove serum protein, followed by fortification with dopamine dissolved in buffer solution to achieve the final concentrations of dopamine as $5 \times 10^{-3} \mathrm{~mol} \mathrm{~L}^{-1}$. After vortexing for $60 \mathrm{~s}$, the mixture was centrifuged for $10 \mathrm{~min}$ at $10,000 \mathrm{rpm}$ to remove the serum protein residues. Supernatant was taken carefully and appropriate volumes of this supernatant were transferred into the electrochemical glass cell and diluted up to the volume with

\begin{tabular}{|c|c|c|c|c|c|}
\hline \multicolumn{6}{|c|}{$\begin{array}{c}\text { TABLE-1 } \\
\text { DETERMINATION RESULTS OF DOPAMINE IN INJECTIONS }\end{array}$} \\
\hline Sample & Labeled $\left(\mathrm{mg} \mathrm{mL}^{-1}\right)$ & Found $\left(\mathrm{mg} \mathrm{mL}^{-1}\right)$ & Added $\left(\mathrm{mg} \mathrm{mL}^{-1}\right)$ & Total found $\left(\mathrm{mg} \mathrm{mL}^{-1}\right)$ & Recovery (\%) \\
\hline \multirow{3}{*}{$\begin{array}{l}\text { Dopamine } \\
\text { hydrochloride }\end{array}$} & \multirow{3}{*}{10} & 9.82 & 10.00 & 20.02 & 102.0 \\
\hline & & 9.27 & 20.00 & 29.48 & 102.3 \\
\hline & & 9.34 & 30.00 & 39.27 & 99.3 \\
\hline
\end{tabular}


the 1.81 buffer solution (containing $0.1 \mathrm{~g} \mathrm{~L}^{-1}$ hypoxanthine). The human serum samples determined parallelly for 7 times by the CVs and the amount of dopamine was determined using $\mathrm{I}_{\mathrm{Pc}}$. The results are shown in Table- 2 .

\begin{tabular}{ccccc}
\multicolumn{5}{c}{ TABLE-2 } \\
\multicolumn{5}{c}{$\begin{array}{c}\text { DETERMINATION RESULTS OF DOPAMINE } \\
\text { IN HUMAN SERUM SAMPLES }(\mathrm{n}=7)\end{array}$} \\
\hline \multirow{2}{*}{ Sample } & $\begin{array}{c}\text { Added } \\
\left(\mathrm{mol} \mathrm{L}^{-1}\right)\end{array}$ & $\begin{array}{c}\text { Found } \\
\left(\mathrm{mol} \mathrm{L}^{-1}\right)\end{array}$ & $\begin{array}{c}\text { Recovery } \\
(\%)\end{array}$ & $\begin{array}{c}\text { RSD } \\
(\%)\end{array}$ \\
\hline \multirow{3}{*}{ Serum } & 0 & Not detected & - & - \\
& $1.00 \times 10^{-5}$ & $1.06 \times 10^{-5}$ & 106.0 & 2.56 \\
& $2.00 \times 10^{-5}$ & $1.92 \times 10^{-5}$ & 96.0 & 2.74 \\
\hline
\end{tabular}

\section{REFERENCES}

1. U. Bonuccelli, P. Del Dotto and O. Rascol, Parkinsonism Relat. Disord., 15, 44 (2009).

2. B. Winner, P. Desplats, C. Hagl, J. Klucken, R. Aigner, S. Ploetz, J. Laemke, A. Karl, L. Aigner, E. Masliah, E. Buerger and J. Winkler, Exp. Neurol., 219, 543 (2009).
3. Y.S. Zhao, S.L. Zhao, J.M. Huang and F.G. Ye, Talanta, 85, 2650 (2011).

4. J. Chen, Y.P. Shi and J.Y. Liu, J. Chromatogr. A, 1003, 127 (2003).

5. H.X. Zhao, H. Mu, Y.H. Bai, H. Yu and Y.M. Hu, J. Pharm. Anal., 1, 208 (2011).

6. W. Wei, H.J. Wang and C.Q. Jiang, Luminescence, 22, 581 (2007).

7. X.D. Xu, H.M. Shi, L. Ma, W.J. Kang and S. Li, Luminescence, 26, 93 (2011).

8. J. Kim, M. Jeon, K.J. Paeng and I.R. Paeng, Anal. Chim. Acta, 619, 87 (2008).

9. Y. Tinikul, A.J. Mercier and P. Sobhon, Tissue Cell, 41, 430 (2009).

10. A.K.S. Ho and H.H. Loh, Eur. J. Pharmacol., 19, 145 (1972).

11. X.H. Lin, Y.F. Zhang, W. Chen and P. Wu, Sens. Actuators B, 122, 309 (2007).

12. H. Razmi, M. Agazadeh and B. Habibi-A, J. Electroanal. Chem., 547, 25 (2003).

13. Y.Z. Zhou, L.J. Zhang, S.L. Chen, S.Y. Dong and X.H. Zheng, Chin. Chem. Lett., 20, 217 (2009).

14. J. Li and X.Q. Lin, Sens. Actuators B, 124, 486 (2007).

15. M.H. Mashhadizadeh, T. Yousefi and A. Nozad Golikand, Electrochim. Acta, 59, 321 (2012). 